\title{
HUBUNGAN FAKTOR BUDAYA DAN PENGETAHUAN IBU DENGAN PEMBERIAN MAKANAN PENDAMPING ASI DINI PADA BAYI DI BIDAN PRAKTIK MANDIRI DESI FITRIANI OKU
}

\author{
Maya Sartika, SKM., M.K.M \\ Program Studi Kebidanan STIKES AL-MA'ARIF BATURAJA \\ E-mail: mayasartika19@yahoo.co.id
}

\begin{abstract}
ABSTRAK
Latar Belakang: ASI Eksklusif adalah pemberian ASI saja selama 6 bulan tanpa tambahan cairan apapun, setelah bayi berusia enam bulan, bayi baru diberikan MPASI dengan ASI tetap diberikan sampai usia bayi 2 tahun atau lebih. MP-ASI adalah makanan atau minuman yang mengandung zat gizi,diberikan kepada bayi atau anak usia 6-24 bulan guna memenuhi kebutuhan gizi selain dari ASI. Tujuan Penelitian: untuk mengetahui hubungan faktor budaya dan pengetahuan ibu dengan pemberian MP-ASI dini pada bayi usia 6-12 bulan di Bidan Praktik Mandiri Desi Fitriani Baturaja Kabupaten Ogan Komering Ulu Tahun. Metode: Penelitian: ini menggunakan metode analitik dengan pendekatan cross sectional. Populasi dalam penelitian adalah seluruh ibu yang memiliki bayi berusia $6-12$ bulan periode JuniAgustus Tahun 2019 yang berjumlah 47 orang. Analisa data menggunakan analisa univariat dan analisa bivariat dengan menggunakan tabel distribusi dan uji statistik Chi-Square, dengan derajat kepercayaan 95\%. Hasil penelitian: analisa bivariat didapatkan ada hubungan yang bermakna antara faktor budaya terhadap pemberian MP-ASI dini pada bayi usia 6-12 bulan dengan nilai $p$ value 0,016 . Ada hubungan yang bermakna antara pengetahuan terhadap pemberian MP-ASI dini pada bayi usia 6-12 bulanda nilai uji statistik dengan nilai $p$ value 0,042 .
\end{abstract}

Kata Kunci: Faktor Budaya, MP ASI Dini, Pengetahuan

Background: Exclusive breastfeeding is only breastfeeding for 6 months without any additional fluids, after the baby is six months old, new babies are given MPASI with breast milk still given until the baby is 2 years or older. MP-ASI is food or drink that contains nutrients, given to babies or children aged 6-24 months to meet nutritional needs other than breast milk. Research Objective: to determine the relationship between cultural factors and maternal knowledge with early breastfeeding supplementation for infants aged 6-12 months in the Independent Practice Midwife Desi Fitriani Baturaja Ogan Komering Ulu Tahun. Research Method: This uses an analytical method with cross sectional approach. The population in this study were all mothers who had babies aged 6-12 months in the JuneAugust 2019 period, amounting to 47 people. Data analysis uses univariate analysis and bivariate analysis using distribution tables and Chi-Square statistical tests, with a 95\% confidence level. Results: bivariate analysis found that there was a significant relationship between cultural factors and the provision of early breastfeeding for infants aged 6-12 months with a $p$ value of 0.016 . There is a significant relationship between knowledge of early breastfeeding MP in infants aged 6-12 months with a statistical test value with a $p$ value of 0.042 .

Keyword: Cultural Factors, Early Breastfeeding MP, Knowledge 


\section{PENDAHULUAN}

Angka Kematian Ibu (AKI) dan Angka Kematian Bayi (AKB) merupakan salah satu indikator keberhasilan layanan kesehatan di suatu Negara. Badan pusat statistik mengestimasikan AKB di Indonesia pada tahun 2007adalah 34/1000 kelahiran hidup. Angka ini sedikit menurun jika dibandingkan dengan AKB tahun 2002- 2003 yang sebesar 35/1000 kelahiran hidup (DepKes RI, 2008). Ikatan dokter anak Indonesia (IDAI) mencatat kurang dari 10 bayi dan 20 anak balita meninggal dunia setiap jam di Indonesia (Hernawati, 2007). AKB yang tinggi dapat dicegah atau diturunkan apabila setiap bayi hanya diberikan ASI Eksklusif selama 6bulan pertama dari kehidupannya karena ASI adalah makanan yang terbaik bagi bayi (Muthmainnah, 2010).

ASI Eksklusif adalah pemberian hanya ASI saja selama 6 bulan tanpa tambahan cairan apapun, seperti susu formula, jeruk, madu, air teh, air putih dan tanpa pemberian makanan tambahan lain, seperti pisang, bubur susu, biskuit, bubur atau nasi tim. Setelah bayi berusia enam bulan, barulah bayi diberikan2 MPASI dengan ASI tetap diberikan sampai usia bayi 2 tahun atau lebih (Wiji, 2013). MPASI adalah makanan atau minuman yang mengandung zat gizi,diberikan kepada bayi atau anak usia 6-24 bulan guna memenuhi kebutuhan gizi selain dari ASI (Depkes, 2006).

Bayi yang mendapatkan ASI eksklusif berjumlah 30,2\% sedangkan bayi yang telah diberikan MPASI adalah 69,8\% dari seluruh total bayi di Indonesia.

Menurut WHO (2012), prevalensi pemberian ASI di Jawa Tengah pada tahun 2009 sebesar 40,21\%, dan prevalensi tertinggi berada di Kabupaten Banyumas sebesar $87,99 \%$, sedangkan di Kabupaten Sukoharjo pada tahun 2009 adalah sebesar 60,15\% (Dinas Kesehatan Jawa Tengah, 2009).
Rendahnya pemberian ASI Eksklusif oleh ibu menyusui di Indonesia disebabkan oleh faktor internal dan eksternal. Faktor internal meliputi rendahnya pengetahuan dan sikap ibu, dan faktor eksternal meliputi kurangnya dukungan keluarga, masyarakat, petugas kesehatan maupun pemerintah, gencarnya promosi susu formula, faktor sosial budaya serta kurangnya ketersediaan fasilitas pelayanan kesehatan ibu dan anak (Prasetyono, 2009).

ASI sangat penting untuk asupan gizi untuk mencapai tumbuh kembang optimal, di dalam Global Strategy for Infant and Young Child Feeding, WHO/UNICEF merekomendasikan empat hal penting yang harus dilakukan yaitu: pertama memberikan air susu ibu kepada bayi segera dalam waktu 30 menit setelah bayi lahir, kedua memberikan hanya air susu ibu (ASI) saja atau pemberian ASI secara eksklusif sejak lahir sampai bayi berusia 6 bulan, ketiga memberikan makanan pendamping air susu ibu (MPASI) sejak bayi berusia 6 bulan sampai 24 bulan, dan keempat meneruskan pemberian ASI sampai anak berusia 24bulan atau lebih (Muthmainnah, 2010).

Dampak negatif dari pemberian MPASI dini berdasarkan riset yang dilakukan oleh pusat penelitian dan pengembangan gizi dan makanan selama 21 bulan diketahui, bayi yang diberikan makanan tambahan pada usia $<6$ bulan lebih banyak yang terserang diare, batukpilek, dan panas ketimbang bayi yang diberikan ASI saja. Semakin bertambahnya umur bayi, frekuensi terserang diare, batuk-pilek, dan panas semakin meningkat (Eka, dkk 2014). Makanan Pendamping ASI merupakan makanan atau minuman selain ASI yang diberikan untuk memenuhi kebutuhan energi dan zat-zat gizi pada bayi yang tidak tercukupi oleh ASI. 
Makanan pendamping ASI diberikan pada bayi mulai usia 6 bulan hingga usia 24 bulan. Meskipun demikian masih terdapat ibu yang memberikan makanan pendamping ASI pada usia kurang dari 6 bulan. Salah satu faktor yang mempengaruhi waktu pemberian makanan pendamping $\mathrm{ASI}$ adalah faktor budaya (Muthmainnah, 2010).

Menurut William (2006) bahwa pemberian makanan padat yang dimulai sebelum bayi berusia 6 bulan akan meningkatkan risiko alergi. Usus yang telah matang akan mengeluarkan immunoglobulin protein $\lg \mathrm{A}$, yang melapisi usus dan mencegah lewatnya protein allergen yang berbahaya (susu sapi, gandum, dan kacang kedelai adalah contoh umum dari makanan yang menyebabkan alergi bila diberikan terlalu dini).

Hasil studi pendahuluan yang dilakukan pada bulan Maret tahun 2019 melalui wawancara dengan 10 ibu yang memiliki bayi usia 6-12 bulan di Desa Air Paoh, terdapat 6 ibu yang memberikan MP-ASI dini. Enam ibu tersebut mengatakan bahwa ia memberikan MPASI pada saat bayinya berusia 40 hari karena ada jamu cekok dari dukun bayi . Bayi juga sudah diberi MP-ASI berupa bubur tepung halus sejak usia 2 bulan dan 4 lainya tidak memberikan MP-ASI.

Masih rendahnya pengetahuan ibu tentang pemberian makanan pendamping ASI dipengaruhi oleh banyak faktor. Menurut Notoadmodjo (2003) faktor-faktor yang mempengaruhi pengetahuan yaitu umur, pendidikan, pekerjaan, dan sosial ekonomi. Dengan didasari pengetahuan diharapkan sikap dan perilaku akan mengikuti, karena perilaku yang didasari oleh pengetahuan akan lebih langgeng dari pada perilaku yang tidak didasari oleh pengetahuan.

Selain itu faktor yang turut mempengaruhi pemberian MP-ASI adalah fakor budaya yang ada dalam lingkungan masyarakat. kebudayaan adalah keseluruhan yang kompleks yang didalamnya terkandung ilmu pengetahuan, kepercayaan, dan kemampuan kesenian, moral, hukum, adat istiadat, dan kemampuan lain serta kebiasaankebiasaan yang didapat manusia sebagai anggota masyarakat. Keyakinan atau budaya yang ada di masyarakat berpengaruh terhadap pemberian MPASI. (Notoatmodjo, 2008)

\section{METODE PENELITIAN}

Jenis penelitian ini menggunakan metode survei analitik yaitu penelitian yang mencoba menggali bagaimana dan mengapa fenomena kesehatan itu terjadi dan dengan pendekatan cross sectional dimana variabel independen dan variabel dependen dikumpulkan bersama-sama (Notoatmodjo, 2010). Populasi penelitian ini adalah seluruh ibu yang memiliki bayi berusia 6-12 bulan di Bidan Praktik Mandiri Desi Fitriani Baturaja Kabupaten Ogan Komering Ulu periode Juni-Agustus Tahun 2019 yang berjumlah 47 orang. Sampel adalah sebagian yang diambil dari keseluruhan objek yang diteliti dan dianggap mewakili populasi tersebut. Metode pengambilan sampel dengan Total sampling yaitu ibu-ibu yang memiliki bayi yang datang ke Bidan Praktik Mandiri Desi Fitriani Baturaja Kabupaten Ogan Komering Ulu periode Juni-Agustus Tahun 2019 yang berjumlah 47 orang.

\section{HASIL PENELITIAN}

Analisa ini dilakukan untuk mengetahui hubungan antara variabel dependen (pemberian MP-ASI dini) serta variabel independen (faktor budaya, pengetahuan). Uji statistik yang digunakan adalah uji chisquare dengan batas kemaknaan $p$ value $\leq 0,05$ artinya ada hubungan yang bermakna (signifikan) dan bila $p$ value > 
0,05 maka tidak ada hubungan yang bermakna

1. Faktor Budaya
Untuk mengetahui hubungan faktor budaya dengan pemberian MP-ASI dini pada bayi usia 6-12 bulan dilakukan uji Chi Square

Tabel. 1

Hubungan Faktor Budaya dengan Pemberian MP ASI Dini Pada Bayi Usia 6-12 Bulan di BPM Desi Fitriani OKU

\begin{tabular}{|c|c|c|c|c|c|c|c|c|}
\hline \multirow{3}{*}{ No } & \multirow{3}{*}{$\begin{array}{l}\text { Faktor } \\
\text { Budaya }\end{array}$} & \multicolumn{4}{|c|}{ Pemberian MP-ASI dini } & \multirow{2}{*}{\multicolumn{2}{|c|}{ Jumlah }} & \multirow{3}{*}{$P$ value } \\
\hline & & \multicolumn{2}{|c|}{$\mathrm{Ya}$} & \multicolumn{2}{|c|}{ Tidak } & & & \\
\hline & & $\mathrm{F}$ & $\%$ & $\mathrm{~F}$ & $\%$ & $\mathrm{~F}$ & $\%$ & \\
\hline 1 & Patuh & 24 & 88,9 & 3 & 11,1 & 27 & 100 & \multirow{2}{*}{0,016} \\
\hline . & Tidak Patuh & 11 & 55,0 & 9 & 45,0 & 20 & 100 & \\
\hline & Jumlah & 35 & 74,5 & 12 & 25,5 & 47 & 100 & \\
\hline
\end{tabular}

Berdasarkan tabel.1 dapat dilihat bahwa responden yang memberikan MP-ASI dini pada responden yang patuh dengan budaya yaitu sebanyak 24 responden $(88,9 \%)$ lebih tinggi dibanding responden yang tidak patuh dengan budaya yaitu sebanyak 11 responden (55,0\%). Hasil Uji statistik chi square diperoleh $\rho$ value $=$ 0,016 , ini berarti terdapat hubungan faktor budaya terhadap pemberian MP-ASI dini.

\section{Pengetahuan}

Tabel. 2

Hubungan pengetahuan ibu dengan pemberian MP ASI Dini pada bayi usia 6-12 bulan di BPM Desi Fitriani Baturaja OKU

\begin{tabular}{|c|c|c|c|c|c|c|c|c|}
\hline \multirow[t]{2}{*}{ No } & \multirow[t]{2}{*}{ Pengetahuan } & \multicolumn{4}{|c|}{ Pemberian MP-ASI dini } & \multirow[t]{2}{*}{$\Sigma$} & \multirow[t]{2}{*}{$\%$} & \multirow[t]{2}{*}{$\mathrm{P}$ value } \\
\hline & & $\mathrm{F}$ & $\%$ & $\mathrm{~F}$ & $\%$ & & & \\
\hline 1 & Kurang & 22 & 88,0 & 3 & 12,0 & 25 & 100 & \\
\hline 2 & Baik & 13 & 59,1 & 9 & 40,9 & 22 & 100 & 0,042 \\
\hline & Jumlah & 35 & 74,5 & 12 & 25,5 & 47 & 100 & \\
\hline
\end{tabular}

Berdasarkan tabel 5.5 dapat dilihat bahwa responden yang memberikan MP-ASI dini pada responden berpengetahuan kurang yaitu sebanyak 22 responden $(88,4 \%)$ lebih tinggi dibanding responden pengetahuan baik yang memberikan MPASI dini yaitu sebanyak 13 responden (59,1\%). Hasil Uji statistik chi square diperoleh $\rho$ value $=0,042$, ini berarti terdapat hubungan pengetahuan ibu terhadap pemberian MP-ASI dini.

\section{PEMBAHASAN}

Hubungan faktor budaya dengan pemberian MP ASI dini pada bayi usia 612 bulan di BPM Desi Fitriani Baturaja Kabupaten Ogan Komering Ulu tahun 2019.

Pada penelitian ini variabel faktor budaya dikategorikan menjadi 2 yaitu patuh (jika responden patuh terhadap budaya yang ada di masyarakat) dan tidak patuh (jika responden patuh terhadap budaya yang ada di masyarakat). Pada hasil analisa 
biavariat responden yang memberikan MP-ASI dini pada responden yang patuh dengan budaya yaitu sebanyak 24 responden $(88,9 \%)$ lebih tinggi dibanding responden yang tidak patuh dengan budaya yaitu sebanyak 11 responden $(55,0 \%)$. Hasil Uji statistik chi square diperoleh value $=0,016$, menyatakan ada hubungan yang bermakna antara faktor budaya terhadap pemberian MP-ASI dini pada bayi usia 6-12 bulan di BPM Desi Fitriani Baturaja Kabupaten OKU tahun 2019 terbukti. Hasil penelitian ini sejalan dengan hasil penelitian yang dilakukan oleh (Ginting, 2012) yang menyebutkan bahwa ada hubungan yang bermakna antara faktor sosial budaya dengan pemberian MPASI dini. Budaya atau kebiasaan memberi MP-ASI $<6$ bulan di masyarakat adalah salah satu faktor yang mempengaruhi ibu dalam pemberian MPASI dini.

Penelitian yang dilakukan Heppy dan Rahmawati (2018) menunjukkan bahwa ada hubungan antara faktor budaya dengan waktu pemberian MPASI di Desa Peniron Kecamatan Pejagoan Kabupaten Kebumen 2016. Pemberian makanan pendamping ASI setelah bayi lahir merupakan kebiasaan turun temurun dalam keluarga dan jika tidak melakukannya maka dianggap melanggar kebiasaan dalam keluarga (Lismintari, 2010)

Hubungan pengetahuan ibu yang berhubungan dengan pemberian imunissai pada ibu hamil di BPM Desi Fitriani Baturaja Kabupaten Ogan Komering Ulu tahun 2019.

Pada penelitian ini variabel pengetahuan dikategorikan menjadi 2 yaitu responden dengan pengetahuan tiggi (jika responden dapat menjawab dengan benar $70 \%$ ) dan responden dengan pengetahuan rendah (jika responden menjawab dengan benar < $70 \%$. Pada hasil analisa biavariat responden yang memberikan MP-ASI dini pada responden berpengetahuan kurang yaitu sebanyak 22 responden $(88,4 \%)$ lebih tinggi dibanding responden pengetahuan baik yang memberikan MPASI dini yaitu sebanyak 13 responden (59,1\%).

Hasil Uji statistik chi square diperoleh value $=0,042$, menyatakan ada hubungan yang bermakna antara pengetahuan ibu terhadap pemberian MP-ASI dini pada bayi usia 6-12 bulan di BPM Desi Fitriani Baturaja Kabupaten OKU tahun 2019 terbukti.

Menurut Notoatmodjo, (2007) Pengetahuan adalah merupakan hasil "tahu" dan ini terjadi setelah orang melakukan penginderaan suatu objek tertentu. Penginderaan terjadi melalui panca indera manusia yakni: pengetahuan, penciuman, rasa dan raba sebagai dasar pegetahuan manusia diperoleh melalui mata dan telinga. Pengetahuan atau kognitif merupakan dominan yang sangat penting untuk terbentuknya tindakan seseorang.

Rendahnya pengetahuan ibu tentang pemberian makanan pendamping ASI dipengaruhi oleh banyak faktor. Menurut Notoadmodjo (2003) faktor-faktor yang mempengaruhi pengetahuan yaitu umur, pendidikan, pekerjaan, dan sosial ekonomi. Dengan didasari pengetahuan diharapkan sikap dan perilaku akan mengikuti, karena perilaku yang didasari oleh pengetahuan akan lebih langgeng dari pada perilaku yang tidak didasari oleh pengetahuan.

Penelitian diatas dapat ditarik asumsi bahwa pengetahuan ibu mempengaruhi pemberian MP-ASI dini. Hal ini menunjukkan bahwa pengetahuan tentang pentingnya manfaat pemberian ASI Eksklusif akan mempengaruhi perilaku ibu untuk memberikan MP-ASI dini. 
Selain itu faktor budaya yang ada dalam lingkungan masyarakat turut mempengaruhi perilaku ibu untuk memberikan MP-ASI dini. Sebab kebudayaan merupakan keseluruhan yang kompleks yang didalamnya terkandung ilmu pengetahuan, kepercayaan, dan kemampuan kesenian, moral, hukum, adat istiadat, dan kemampuan lain serta kebiasaan-kebiasaan yang didapat manusia sebagai anggota masyarakat. Keyakinan atau budaya yang ada di masyarakat berpengaruh terhadap pemberian MPASI. (Notoatmodjo, 2008)

\section{KESIMPULAN}

1. Dari 47 responden didapatkan responden yang memberikan MP-ASI dini sebesar 35 responden (74,5\%) sedangkan responden yang tidak memberikan MP-ASI dini sebesar 12 responden $(25,5 \%)$.

2. Dari 47 responden didapatkan responden yang patuh dengan budaya sebesar 27 responden (57,4\%), sedangkan responden yang tidak patuh sebesar 20 responden (42,6\%)

3. Dari 47 responden didapatkan responden yang berpengetahuan kurang sebesar 25 responden $(53,2 \%)$, responden berpengetahuan baik sebesar 22 responden (46,8\%).

4. Ada hubungan yang bermakna antara faktor budaya terhadap pemberian MP-ASI dini pada bayi usia 6-12 bulan di BPM Desi Fitriani Baturaja Kabupaten OKU tahun 2019. Hal tersebut dibuktikan pada nilai uji statistik dengan nilai $p$ value 0,016 .

5. Ada hubungan yang bermakna antara pengetahuan terhadap pemberian MP-ASI dini pada bayi usia 6-12 bulan di BPM Desi Fitriani Baturaja Kabupaten OKU tahun 2019. Hal tersebut dibuktikan pada nilai uji statistik dengan nilai $p$ value 0,046 .

\section{DAFTAR PUSTAKA}

1. Arikunto, Suharsimi. 2010. Prosedur Penelitian Suatu Pendekatan Praktik. Jakarta : Rineka Cipta

2. Emilia K. (2008). Buku Saku Manajemen Laktasi. Jakarta: EGC

3. Fitrianti, Eka. 2011. Faktor-faktor yang mempengaruhi lbu dalam Pemilihan Makanan Pendamping Air Susu Ibu di Wilayah Kerja UPTD Puskesmas Sukaraya Tahun 2011. Baturaja : Akper Al-Ma'arif

4. Ficha Elly Kusumasari. 2016 .Hubungan Pengetahuan lbu tentang Makanan Pendamping ASI dengan Status Gizi pada Anak di Wilayah Kerja Puskesmas Juwiring Klaten. Universitas Muhammaddiyah Surakarta

5. Fithriatul Muthmainah. 2010. Faktorfaktor yang berhubungan dengan pengetahuan ibu dalam memberikan makanan pendamping Air Susu Ibu di Puskesmas Pamulang Tahun 2010. UIN Syarif Hidayatullah Jakarta

6. Krisnatuti, Diah. 2012. Makanan Pendamping ASI. Jakarta : Puspa Sehat

7. Marimbi, Hanum. 2010. Tumbuh Kembang, Status Gizi dan Imunisasi Dasar pada Balita. Yogyakarta : Nuha Medika

8. Madjid, Abdul. 2010. Asuhan Persalinan Normal. Jakarta : Jaringan Nasional Pelatihan Klinik;

9. Nakita. 2012. Dampak Pemberian MP-ASI Dini dan Terlambat. http:www.nakita.com diakses 01 April 2013

10. Notoatmodjo, Soekidjo. 2007. Promosi Kesehatan Teori dan Aplikasi. Jakarta : Rineka Cipta

11. Notoatmodjo, Soekidjo. 2010. Metode Penelitian Kesehatan. Jakarta : Rineka Cipta 
12. Peraturan Pemerintah Republik Indonesia Nomor 33 tahun 2012 tentang Pemberian ASI Ekslusif

13. Roesli, U. (2008). Manfaat ASI dan Menyusui. Jakarta: Balai Penerbit Fakultas Kedokteran Universitas Indonesi

14. Ronald.2010.. Perencanaan Pangan dan Gizi. Jakarta: Bumi Aksara.

15. Yulius, Oscar. 2010. IT Kreatif : SPSS 18. Yogyakarta : Panser Pustaka

16. Wiji Lismintari, L. (2013). FaktorFaktor yang Mempengaruhi Pemberian Makanan Pendaming ASI Dini Pada Bayi Usia 0-6 Bulan di Wilayah Kerja Puskesmas Teluk Dalam Kecamatan Tenggarong Seberang Kabupaten Tenggarong Seberang.

http://www.pasca.unhas.ac.id/jurnal/fil es diakses tanggal 11 Juni 2019.

17. William (2016). Hubungan Pengetahuan Dan Sikap Ibu dengan Pemberian MPASI di Kelurahan PB. Selayang.

http://www.digilib.unimus.ac.id diakses tanggal 14 Mei 2019. 